\title{
Pengukuran Tingkat Keseimbangan Node dan Place di Kawasan Transit Oriented Development (TOD) Terminal Joyoboyo, Surabaya
}

\author{
Alita Nadyla dan Siti Nurlaela \\ Departemen Teknik Sipil, Institut Teknologi Sepuluh Nopember (ITS) \\ Corresponding Author: siti.nurlaela@postgrad.curtin.edu.au
}

\section{ARTIKEL INFO}

\section{Informasi Artikel}

Artikel masuk :

Artikel revisi :

Artikel diterima :

\begin{abstract}
ABSTRAK
Kawasan Terminal Joyoboyo merupakan kawasan strategis yang saat ini telah dilayani oleh dua (2) moda transportasi umum, yaitu bus dan lyn. Berdasarkan RDTRK UP. Wonokromo tahun 2017, kawasan ini diarahkan sebagai hub antara Surotram dan Boyorail sebagai Angkutan Massal Cepat (AMC). TOD dan node-place merupakan konsep yang mengintegrasikan antara titik transit dan kawasan di sekitarnya. Namun, penerapan konsep TOD belum tercermin pada kawasan ini. Maka diperlukan pengukuran indeks node dan place kawasan TOD berdasarkan konsep node-place model, sehingga dapat diketahui keseimbangan peran kawasan TOD Terminal Joyoboyo sebagai kawasan berbasis node-place model. Penelitian ini dilakukan dengan identifikasi karakteristik kawasan berdasarkan kriteria dan parameter TOD serta node-place model. Teknik analisis weighted multi criteria analysis digunakan untuk mengetahui tingkat keseimbangan antara node dan place index. Hasil penelitian ini menunjukan bahwa kawasan transit joyoboyo masuk kedalam kategori unsustained place. Hal ini dikarenakan node index sebesar 0,48, sedangkan place index sebesar 0,64 .
\end{abstract}

\section{Kata Kunci}

Kawasan Terminal Joyoboyo Surabaya, Node-Place Model, Transit Oriented Development, Weighted Multi Criteria Analysis. transportasi yang ada di Surabaya adalah dengan penggunaan transportasi publik. Transportasi publik tersebut akan lebih maksimal apabila memperhatikan prinsip land use transport integration atau urban development atau yang biasa disebut Transit Oriented Development (TOD) [3][4], dan [5]. Transit Oriented Development (TOD) adalah penggunaan lahan secara mix-used yang mendorong masyarakat untuk tinggal dan beraktifitas di area kawasan yang memiliki fasilitas transportasi umum dan menurunkan kebiasaan masyarakat untuk mengendarai mobil pribadi [6]. TOD sendiri sudah banyak berhasil mengurangi angka penggunaan kendaraan pribadi di seluruh dunia. Salah satunya adalah di Curitiba, Brazil, yang berhasil mengurangi jumlah kendaraan atau kemacetan yang ada, serta membuat mixed land use dengan pembuatan perumahan bagi urban sprawl di kota tersebut. Pada awal tahun 1970, hanya $7 \%$ penduduk kota tersebut yang menggunakan transportasi publik, namun dikarenakan penerapan TOD, pada tahun 2006, hampir 75\% penduduk menggunakan transportasi publik untuk bekerja. Jumlah tersebut sama dengan 23.000 penumpang per jam [7].

Selain konsep TOD, terdapat konsep Node-Place Model (N-P Model) sebagai kerangka kerja untuk memudahkan pemodelan akan pengembangan area transit dan identifikasi pengembangan potensi strategis [8]. Node-Place Model ini berdasarkan teori "land-use and transport feedback cycle" [9]. N-P model ditujukan 
untuk mencapai keseimbangan antara jaringan transportasi dan land-use yang ada pada kawasan transit tersebut [10]. Node adalah jaringan transportasi publik yang ada di suatu kawasan, sedangkan place adalah lokasi potensial dimana terjadi interaksi antar manusia. Ketidak-seimbangan node-place dapat ditandai dengan beberapa hal, saat node dan place sama-sama rendah atau sama-sama tinggi, dan node lebih tinggi dibandingkan dengan place, begitu juga sebaliknya [8].

Kota Surabaya belum menerapkan konsep TOD pada kawasan yang merupakan transit point bagi angkutan umum yang ada, sehingga keseimbangan pada nodeplace model belum tercipta. Penduduk dan kegiatan yang ada lebih banyak terpusat pada tempat yang susah dijangkau angkutan umum, sehingga membuat kendaraan pribadi lebih banyak digunakan. Hal itu dikarenakan design yang ada di kawasan transit tersebut dapat dikatakan belum baik, yang ditandai dengan tidak terintegrasinya jalur pedestrian dengan tempat-tempat beraktivitas, misalnya kawasan sekitar Terminal Joyoboyo, kuantitas dan kualitas dari fasilitas pedestrian sangatlah kurang, sehingga pejalan kaki tidak memiliki aksesnya. Meskipun kawasan tersebut sudah berdekatan dengan lokasi transit terminal, kondisi lalu lintas di kawasan ini tergolong buruk dilihat dari rata-rata VCR sebesar 0,85. Hal tersebut mengindikasikan belum terdapat integrasi yang baik antara kegiatan yang berkembang pada kawasan transit dengan Terminal Joyoboyo karena belum didukung oleh desain kawasan yang ramah bagi pejalan kaki/pesepeda [11].

Padahal Pemerintah Kota Surabaya telah memiliki rencana untuk mengurangi kemacetan, salah satunya dengan mengurangi ketergantungan masyarakat kota tersebut akan penggunaan kendaraan pribadi, yaitu perencanaan angkutan massal cepat yang terdiri dari angkutan monorail untuk koridor Barat-Timur dan tram untuk koridor Utara-Selatan. Terminal Joyoboyo merupakan lokasi rencana $h u b$ (titik temu) Surotram dan Boyorail atau yang biasa disebut juga dengan Angkutan Massal Cepat (AMC), yang direncanakan dibangun pada tahun 2027-2037, lalu secara automatis terminal ini juga akan dilalui oleh feeder dan trunk [2]. Berdasarkan hal tersebut, kawasan TOD Terminal Joyoboyo membutuhkan pengukuran indeks node dan place berbasiskan konsep node-place model yang kemudian akan mengetahui keseimbangan antara jaringan transportasi yang tersedia, dengan aktivitas yang ada di kawasan sekitar terminal tersebut. Sehingga nantinya diharapkan menjadi rekomendasi dalam mendukung urban design guidelines kawasan TOD Terminal Joyoboyo, Surabaya.

\section{METODE PENELITIAN}

\section{A. Metode Pengumpulan Data}

Pengumpulan data dilakukan dengan cara melakukan survei primer ataupun survei sekunder. Untuk mendapatkan data mengenai karakteristik kawasan transit Terminal Joyoboyo dilakukan menggunakan teknik pengumpulan data berupa observasi lapangan serta pengamatan citra satelit. Selain itu juga digunakana survei instansional ke beberapa stakeholders terkait seperti Dinas Perhubungan dan Dinas Perumahan Rakyat dan Kawasan Permukiman, Cipta Karya dan Tata Ruang Kota Surabaya.

\section{B. Variabel Penelitian}

Tabel 1. Indikator, Variabel dan Sub Variabel Penelitian

\begin{tabular}{|c|c|c|}
\hline Indikator & Variabel & Sub Variabel \\
\hline \multirow{14}{*}{$\begin{array}{l}\text { Transportation } \\
\text { / Node }\end{array}$} & Ketersediaan Jalur & Keberadaan Jalur \\
\hline & Pedestrian yang & Pejalan Kaki \\
\hline & Terintegrasi dengan & Konektivitas Jalur \\
\hline & Local Destination & Pejalan Kaki \\
\hline & Lebar Jalur Pedestrian & Main Street \\
\hline & yang Memadai & Residential Street \\
\hline & $\begin{array}{c}\text { Kondisi Jalur Pejalan } \\
\text { Kaki }\end{array}$ & $\begin{array}{c}\text { Sidewalk yang Aman } \\
\text { Kenyamanan Berjalan } \\
\text { Jauh }\end{array}$ \\
\hline & & Jenis Jaringan Trayek \\
\hline & Aksesibilitas Bus dan & Tipe dan Kelas Jalan \\
\hline & Lyn & Lokasi Terminal \\
\hline & & Frekuensi Harian \\
\hline & & Jarak Terminal ke \\
\hline & Aksesibilitas Mobil & $\begin{array}{c}\text { Akses Jalan Raya } \\
\text { Terdekat }\end{array}$ \\
\hline & & Kapasitas Parkir Mobil \\
\hline \multirow{15}{*}{$\begin{array}{l}\text { Landuse / } \\
\text { Place }\end{array}$} & $\begin{array}{c}\text { Koefisien Dasar } \\
\text { Bangunan }\end{array}$ & - \\
\hline & Koefisien Lantai & - \\
\hline & Bangunan & \\
\hline & Kepadatan Kawasan & Kepadatan Bangunan \\
\hline & & Perumahan \\
\hline & & Kepadatan Pekerjaan \\
\hline & & Presentase Residential \\
\hline & Presentase Land Use & Presentase \\
\hline & & Non-Residential \\
\hline & $\begin{array}{c}\text { Jumlah Penduduk Pada } \\
\text { Kawasan }\end{array}$ & - \\
\hline & \multirow{4}{*}{ Jumlah Pekerja } & $\begin{array}{l}\text { Retail, hotel, dan } \\
\text { catering }\end{array}$ \\
\hline & & $\begin{array}{c}\text { Edukasi, kesehatan, } \\
\text { dan budaya }\end{array}$ \\
\hline & & $\begin{array}{l}\text { Administrasi, dan } \\
\text { servis }\end{array}$ \\
\hline & & Industri dan distribusi \\
\hline & Degree of functional mix & - \\
\hline
\end{tabular}

Dalam melakukan analisis kesesuaian kawasan transit digunakan beberapa variabel penelitian sebagai tolak ukur. Penentuan dari variabel penelitian ini didasarkan pada hasil sintesa dari berbagai pustaka ilmiah. Variabel tersebut terdiri dari variabel TOD dan node-place model, yang kemudian digolongkan menjadi indikator transportasi/node dan landuse/place. Tabel 1 merupakan variabel dari penelitian ini.

\section{Metode Analisis}

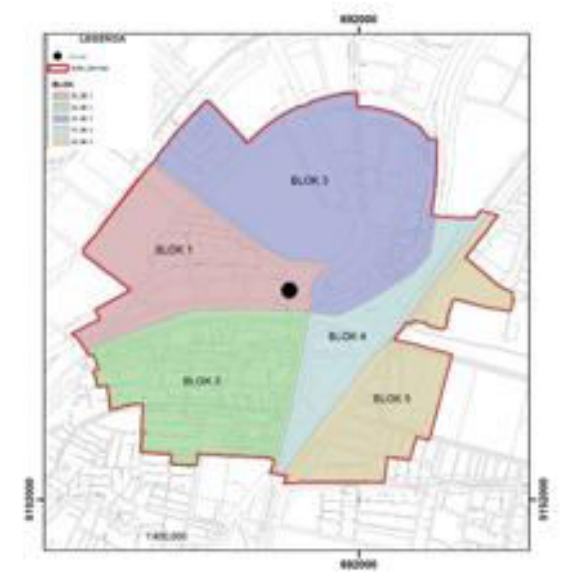

Gambar 1. Ruang Lingkup Wilayah. 
Tabel 2. Kriteria dan Bobot Variabel serta Sub Variabel yang

\begin{tabular}{|c|c|c|c|}
\hline \multicolumn{4}{|c|}{ Digunakan } \\
\hline Variabel & Sub Variabel & Kriteria & Bobot \\
\hline $\begin{array}{l}\text { Ketersediaan Jalur } \\
\text { Pedestrian yang }\end{array}$ & $\begin{array}{c}\text { Keberadaan Jalur } \\
\text { Pejalan Kaki }\end{array}$ & $100 \%$ & 1 \\
\hline Terintegrasi dengan & Konektivitas & & \\
\hline Local Destination & $\begin{array}{c}\text { Jalur Pejalan } \\
\text { Kaki }\end{array}$ & 1 menit $=10$ meter & 1 \\
\hline Lebar Jalur & Main Street & 1,8 meter & 1 \\
\hline $\begin{array}{c}\text { Pedestrian yang } \\
\text { Memadai }\end{array}$ & Residential Street & 1,2 meter & 1 \\
\hline \multirow[t]{3}{*}{$\begin{array}{l}\text { Kondisi Jalur } \\
\text { Pejalan Kaki }\end{array}$} & $\begin{array}{c}\text { Sidewalk yang } \\
\text { Aman }\end{array}$ & $\begin{array}{c}\text { Penerangan yang } \\
\text { memadai dan } \\
\text { fasilitas } \\
\text { penyebrangan jalan }\end{array}$ & 1 \\
\hline & $\begin{array}{l}\text { Kenyamanan } \\
\text { Berjalan Jauh }\end{array}$ & Terdapat peneduhan & 1 \\
\hline & $\begin{array}{c}\text { Jenis Jaringan } \\
\text { Trayek }\end{array}$ & $\begin{array}{c}\text { Terletak dalam } \\
\text { jaringan trayek } \\
\text { antar kota dalam } \\
\text { provinsi }\end{array}$ & 0.82 \\
\hline \multirow[t]{3}{*}{$\begin{array}{l}\text { Aksesibilitas Bus } \\
\text { dan Lyn }\end{array}$} & $\begin{array}{l}\text { Tipe dan Kelas } \\
\text { Jalan Lokasi } \\
\text { Terminal }\end{array}$ & $\begin{array}{l}\text { Terletak di jalan } \\
\text { arteri atau kolektor } \\
\text { Kelas jalan minimal } \\
\text { IIIB }\end{array}$ & 0.78 \\
\hline & $\begin{array}{c}\text { Frekuensi Harian } \\
\text { Jarak Terminal }\end{array}$ & 12 kendaraan/jam & 0.91 \\
\hline & ke Akses Jalan & Minimal 50 meter & 0.78 \\
\hline Aksesibilitas Mobil & $\begin{array}{c}\text { Raya Terdekat } \\
\text { Kapasitas Parkir } \\
\text { Mobil }\end{array}$ & $\begin{array}{c}\text { Menampung } \\
\text { minimal } 38 \text { mobil. }\end{array}$ & 0.69 \\
\hline $\begin{array}{c}\text { Koefisien Dasar } \\
\text { Bangunan }\end{array}$ & - & Minimal $70 \%$ & 0.87 \\
\hline $\begin{array}{c}\text { Koefisien Lantai } \\
\text { Bangunan }\end{array}$ & - & Minimal $200 \%$ & 0.87 \\
\hline \multirow[t]{3}{*}{ Kepadatan Kawasan } & $\begin{array}{l}\text { Kepadatan } \\
\text { Bangunan } \\
\text { Perumahan }\end{array}$ & $>110$ unit/ha & 0.87 \\
\hline & $\begin{array}{l}\text { Kepadatan } \\
\text { Pekerjaan }\end{array}$ & $>400$ pekerjaan/ha & 0.69 \\
\hline & $\begin{array}{l}\text { Presentase } \\
\text { Residential }\end{array}$ & Residential $20 \%$ & 0.87 \\
\hline Presentase Land Use & $\begin{array}{c}\text { Presentase } \\
\text { Non-Residential }\end{array}$ & $\begin{array}{c}\text { Non-Residential } \\
80 \%\end{array}$ & 0.78 \\
\hline \multirow[t]{2}{*}{$\begin{array}{c}\text { Jumlah Penduduk } \\
\text { Pada Kawasan }\end{array}$} & - & 440 orang/ha & 0.82 \\
\hline & $\begin{array}{l}\text { Retail, hotel, dan } \\
\text { catering } \\
\text { Edukasi. }\end{array}$ & & 0.69 \\
\hline & $\begin{array}{l}\text { kesehatan, dan } \\
\text { budaya }\end{array}$ & 400 pekerja/ha & 0.69 \\
\hline \multirow{2}{*}{ Jumlah Pekerja } & $\begin{array}{c}\text { Administrasi, dan } \\
\text { servis }\end{array}$ & & 0.69 \\
\hline & $\begin{array}{c}\text { Industri dan } \\
\text { distribusi }\end{array}$ & & 0.69 \\
\hline \multicolumn{2}{|c|}{ Degree of functional mix } & - & 0.69 \\
\hline
\end{tabular}

Dalam melakukan analisis pengukuran keseimbangan indeks node dan place kawasan TOD Terminal Joyoboyo, Surabay berbasiskan konsep node-place model dilakukan dengan tiga tahapan analisis yakni:

1. Mengidentifikasi Karakteristik Kawasan Terminal Joyoboyo Beradasarkan Kriteria Parameter NodePlace Model

Tahapan ini dilakukan dengan menggunakan analisis statistik deskriptif. Analisis ini dengan cara mengidentifikasi masing-masing indikator, variabel serta sub variabel penelitian dalam ruang lingkup penelitian yakni $800 \mathrm{~m}$ dari transit point Terminal Joyoboyo, Surabaya. Setelah melakukan radius 800 meter dari titik transit kemudian dilakukan delinasi berdasarkan kesamaan karakteristik kawasan. Kemudian diperoleh 5 Blok sebagai unit analisis penelitian. (Gambar 1)

\section{Menganalisis Indeks Node dan Place Kawasan Terminal Joyoboyo}

Pada analisis ini dilakukan dengan cara membandingkan karakteristik kawasan terhadap kriteria minimal kawasan berprinsip node-place model. Dalam menentukan kriteria tersebut dilakukan dengan cara melakukan sintesa dari berbagai pustaka yang dikemukakan para ahli ataupun dari penelitian sebelumnya. Hasil tersebut kemudian dikalikan dengan bobot setiap sub variabel maupun variabel yang didapat dari kedekatannya dengan indikator yang digunakan oleh penelitian Reene [12]. Tahapan ini menggunakan teknik analisis weighted multi criteria analysis. (Tabel 2)

Setelah membandingkan karakteristik kawasan dengan kriteria node-place model kemudian dihitung indeks setiap sub variabel dengan mengalikannya dengan setiap bobotnya. Indeks variabel didapat dari rata-rata indeks sub variabel yang terdapat di dalamnya. Begitu juga dengan indeks indikator yang merupakan rata-rata indeks variabel.

3. Menganalisis Tingkat Keseimbangan antara Node dan Place dari Node-Place Index Kawasan Terminal Joyoboyo

Hasil dari node dan place index yang sudah didapatkan dari tahapan sebelumnya, kemudian dibandingkan untuk diketahui kelas karakteristik dari Kawasan Terminal Joyoboyo. Proses analisis ini menggunakan analisis statistik deskriptif. Klasifikasi kelas node dan place index dapat dilihat pada Tabel 3.

Tabel 3. Klasifikasi Kelas Titik Transit Berdasarkan Node dan Place

\begin{tabular}{ccc} 
& Index [13] \\
\hline Place Index Range & Node Index Range & Kelas \\
\hline $0,6-1$ & $0,6-1$ & Stress \\
$0-0,49$ & $0-0,49$ & Dependent \\
$0,6-1$ & $0-0,59$ & Unsustained node \\
$0-0,59$ & $0,6-1$ & Unsustained place \\
$0,5-0,59$ & $0,5-0,59$ & Balanced \\
\hline
\end{tabular}

\section{HASIL DAN DISKUSI}

A. Identifikasi Karakteristik Kawasan Terminal Joyoboyo Berdasarkan Kriteria Parameter Node-Place Model

Ruang lingkup penelitian yang merupakan radius 800 $\mathrm{m}$ dari transit point memiliki luas lahan sebesar 180,54 ha. Seluruh blok pada wilayah studi termasuk kedalam wilayah administrasi Kecamatan Wonokromo dan terdiri dari beberapa kelurahan yaitu Kelurahan Darmo, Jagir, Ngagel, Ngagel Rejo, Sawunggaling, dan Wonokromo. 
Tabel 4. Indeks Node dan Place Kawasan Terminal Joyoboyo, Surabaya

\begin{tabular}{|c|c|c|c|c|}
\hline Variabel & Sub Variabel & Kriteria & Bobot & Indeks \\
\hline \multicolumn{5}{|c|}{ Node } \\
\hline Ketersediaan Jalur & Keberadaan Jalur Pejalan Kaki & $100 \%$ & 1 & 0.18 \\
\hline $\begin{array}{c}\text { Pedestrian yang Terintegrasi } \\
\text { dengan Local Destination }\end{array}$ & $\begin{array}{c}\text { Konektivitas Jalur Pejalan } \\
\text { Kaki }\end{array}$ & 1 menit $=10$ meter & 1 & 0.27 \\
\hline Lebar Jalur Pedestrian yang & Main Street & 1,8 meter & 1 & 0.68 \\
\hline Memadai & Residential Street & 1,2 meter & 1 & 0.63 \\
\hline \multirow[t]{3}{*}{ Kondisi Jalur Pejalan Kaki } & Sidewalk yang Aman & $\begin{array}{l}\text { Penerangan yang memadai dan } \\
\text { fasilitas penyebrangan jalan }\end{array}$ & 1 & 0.50 \\
\hline & Kenyamanan Berjalan Jauh & Terdapat peneduhan & 1 & 0.47 \\
\hline & Jenis Jaringan Trayek & $\begin{array}{l}\text { Terletak dalam jaringan trayek } \\
\text { antar kota dalam provinsi }\end{array}$ & 0.82 & 0.48 \\
\hline Aksesibilitas Bus dan Lyn & $\begin{array}{c}\text { Tipe dan Kelas Jalan Lokasi } \\
\text { Terminal }\end{array}$ & $\begin{array}{ll}\text { a. Terletak di jalan arteri atau } \\
\text { kolektor } \\
\text { b. Kelas jalan minimal IIIB }\end{array}$ & 0.78 & 0.42 \\
\hline \multirow{3}{*}{ Aksesibilitas Mobil } & Frekuensi Harian & 12 kendaraan/jam & 0.91 & 0.63 \\
\hline & $\begin{array}{c}\text { Jarak Terminal ke Akses Jalan } \\
\text { Raya Terdekat }\end{array}$ & Minimal 50 meter & 0.78 & 0.86 \\
\hline & Kapasitas Parkir Mobil & $\begin{array}{l}\text { Menampung minimal } 38 \text { mobil. } \\
0.48\end{array}$ & 0.69 & 0.21 \\
\hline \multicolumn{5}{|c|}{ Place } \\
\hline Koefisien Dasar Bangunan & - & Minimal $70 \%$ & 0.87 & 0.51 \\
\hline \multirow{4}{*}{$\begin{array}{l}\text { Koefisien Lantai Bangunan } \\
\text { Kepadatan Kawasan }\end{array}$} & - & Minimal 200\% & 0.87 & 0.24 \\
\hline & $\begin{array}{c}\text { Kepadatan Bangunan } \\
\text { Perumahan }\end{array}$ & $>110$ unit/ha & 0.87 & 0.41 \\
\hline & Kepadatan Pekerjaan & $>400$ pekerjaan/ha & 0.69 & 1.23 \\
\hline & Presentase Residential & Residential $20 \%$ & 0.87 & 1.44 \\
\hline Presentase Land Use & $\begin{array}{c}\text { Presentase } \\
\text { Non-Residential }\end{array}$ & Non-Residential $80 \%$ & 0.78 & 0.25 \\
\hline \multirow[t]{2}{*}{$\begin{array}{l}\text { Jumlah Penduduk Pada } \\
\text { Kawasan }\end{array}$} & - & 440 orang/ha & 0.82 & 1.16 \\
\hline & Retail, hotel, dan catering & & 0.69 & \\
\hline \multirow[t]{3}{*}{ Jumlah Pekerja } & $\begin{array}{c}\text { Edukasi, kesehatan, dan } \\
\text { budaya }\end{array}$ & 400 pekerja/ha & 0.69 & 038 \\
\hline & Administrasi, dan servis & & 0.69 & 0.58 \\
\hline & Industri dan distribusi & & 0.69 & \\
\hline \multirow{2}{*}{\multicolumn{2}{|c|}{ Degree of functional mix }} & - & 0.69 & 0.36 \\
\hline & & \multicolumn{3}{|c|}{0.64} \\
\hline
\end{tabular}

Berdasarkan dari hasil identifikasi, untuk indikator transportasi/node yang memiliki variabel ketersediaan jalur pejalan kaki yang terintegrasi dengan local destination, lebar jalur pejalan kaki, kondisi jalur pejalan kaki, aksesibilitas bus dan lyn, serta aksesibilitas mobil termasuk ke dalam kategori rendah. Hal ini dapat dilihat dari yang pertama adalah variabel ketersediaan jalur pejalan kaki yang terintegrasi dengan local destination, hanya $30 \%$ dari jalan yang ada wilayah penelitian memiliki jalur pedestrian, dan konektivitasnya sebesar 161 menit. Selain itu lebar rata-rata dimensi jalur pedestrian di kawasan Terminal Joyoboyo, pada main street sebesar 2,07 meter, dan untuk residential street sebesar 1,28 meter. Untuk variabel kondisi jalur pedestrian, $85 \%$ sidewalk yang terdapat di wilayah penelitian aman, dan $80 \%$ memiliki kenyamanan berjalan jauh. Sedangkan pada variabel aksesibilitas bus dan lyn, terminal yang berada pada tipe jalan kolektor primer dengan kelas jalan IIIC ini memiliki jenis jaringan trayek yang tidak hanya melayani dalam kota, namun juga dalam provinsi, dengan frekuensi harian 14 kendaraan/jam. Variabel pada indikator transportasi/node yang terakhir yaitu aksesibilitas mobil, memili sub variabel jarak terminal ke akses jalan raya terdekat sejauh 93 meter, dengan kapasitas parkir mobil sebanyak 20 mobil.

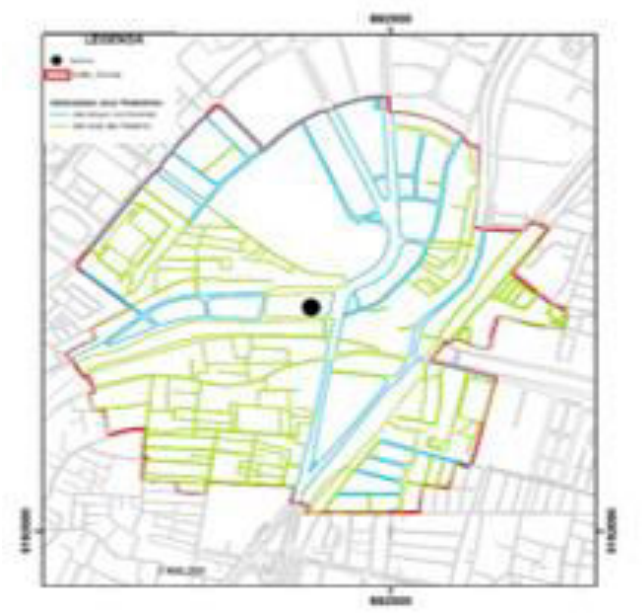

Gambar 2. Peta Keberadaan Jalur Pedestrian.

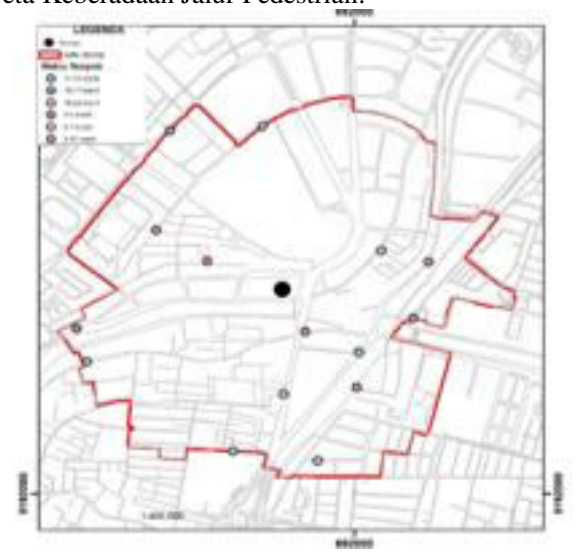


Gambar 3. Peta Konektivitas Jalur Pedestrian.

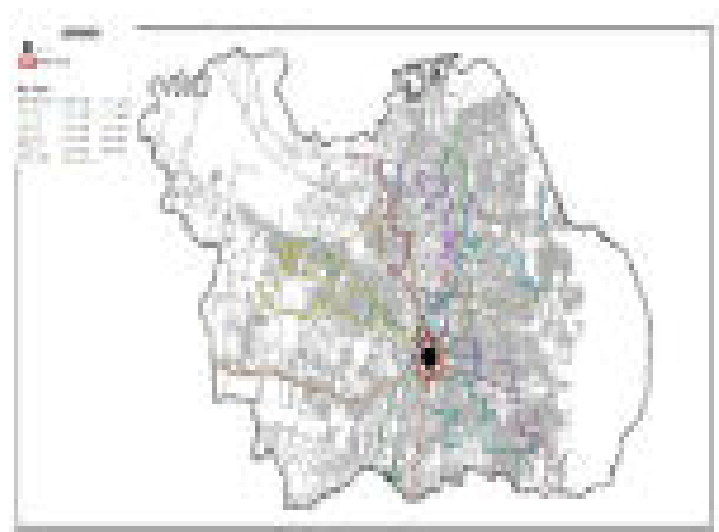

Gambar 4. Peta Jenis Jaringan Trayek.

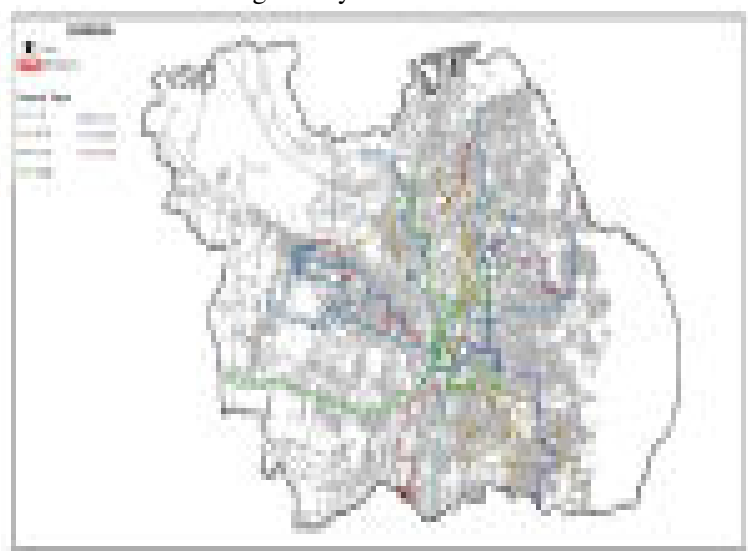

Gambar 5. Peta Frekuensi Harian.

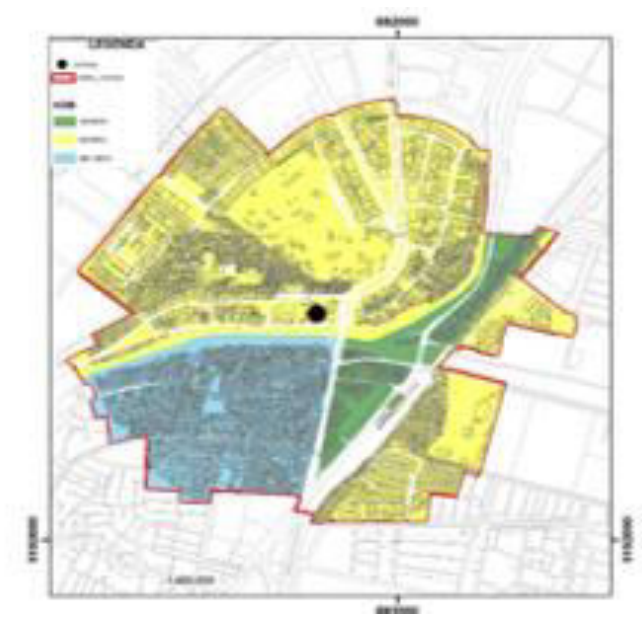

Gambar 6. Peta Koefisien Dasar Bangunan.

Namun, untuk indikator land use/place Kawasan Terminal Joyoboyo sudah tinggi. Jika dilihat dari variabel KDB, rata-rata setiap bloknya adalah $69 \%$. Hal tersebut berdampak kepada variabel KLB, yang rata-rata setiap bloknya adalah 95\%. . Jika ditinjau dari variabel kepadatan kawasan, untuk sub variabel kepadatan bangunan perumahan masih tegolong cukup tinggi. Hal ini dikarenakan kepadatan bangunan perumahan di kawasan tersebut sebesar 87,82 bangunan/ha. Sedangkan untuk kepadatan pekerjaan, di kawasan transit ini sebesar 1205,1 pekerjaan/ha atau dengan kata lain ketersediaan pekerjaan pada kawasan Terminal Joyoboyo ini sangat tinggi. Pada variabel penggunaan lahan, terbagi menjadi dua (2) sub variabel, yaitu residential dan non residential. Penggunaan lahan residential di wilayah penelitian ini sebesar 56\%. Sedangkan untuk penggunaan

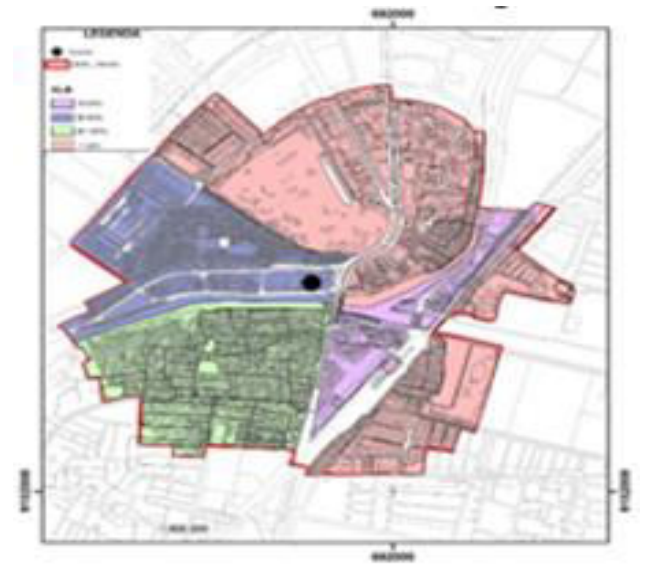

Gambar 7. Peta Koefisien Lantai Bangunan.

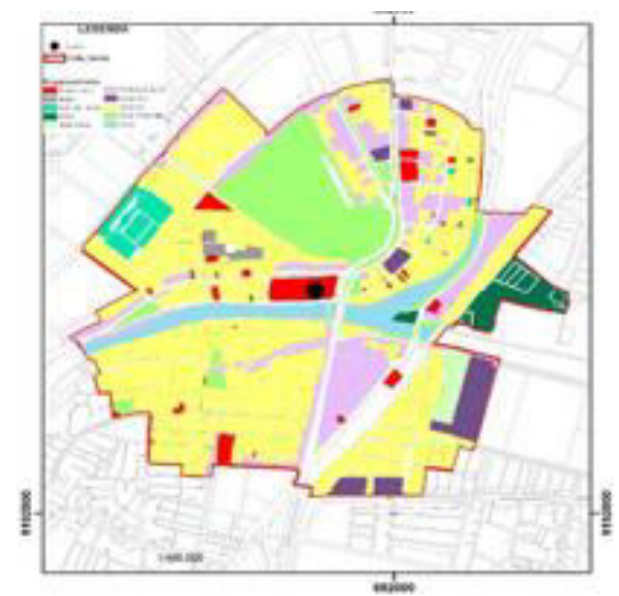

Gambar 7. Penggunaan Lahan.

lahan non residential, dibagi lagi menjadi perkantoran sebesar 9\%, komersial 14\%, fasilitas umum 20\%, dan industri $1 \%$. Dengan kata lain penggunaan lahan non residential pada kawasan Terminal Joyoboyo sebesar 44\%. Besaran penggunaan lahan tersebut berdampak terhadap variabel jumlah penduduk, yaitu sebesar 31.336, dan variabel jumlah pekerja sebesar 33.334. Dari variabel jumlah pekerja kemudian didapatkan degree of multifunctional mix sebesar 0,88 .

\section{B. Analisis Indeks Node dan Place Kawasan Terminal Joyoboyo}

Dalam menganalisis indeks node dan place kawasan transit, dilakukan dengan cara menghitung karakteristik masing-masing variabel ataupun sub variabel dibagi dengan kriteria yang telah ditentukan sebelumnya. Hasil 
tersebut kemudian dikali dengan bobot masing-masing. Setelah mendapatkan indeks masing-masing variabel ataupun sub variabel terhadap kriteria minimal nodeplace model, kemudian hasil tersebut dirata-ratakan berdasarkan indikator (node, dan place). Tabel 4 merupakan perhitungan indeks node dan place di kawasan Terminal Joyoboyo.

C. Analisis Tingkat Keseimbangan antara Node dan Place dari Node-Place Index Kawasan Terminal Joyoboyo

Pada perhitungan yang sudah dilakukan di atas, telah diketahui indeks dari node dan place pada Kawasan Terminal Joyoboyo. Node index pada wilayah penelitian adalah 0,48. Selain itu, place index yang didapatkan adalah 0,64. Dari nilai kedua indeks tersebut, didapatkan bahwa tingkat keseimbangan Kawasan Terminal Joyoboyo adalah termasuk unsustained place, yaitu memiliki node index antara 0-0,59 dan place index antara $0,5-1$.

\section{KESIMPULAN}

Berdasarkan dari hasil analisis dapat disimpulkan bahwa kawasan Terminal Joyoboyo memiliki node index sebesar 0,48, dan place index sebesar 0,64. Dengan indeks tersebut, kawasan Terminal Joyoboyo tergolong kategori unsustained place. Artinya, pengembangan kawasan Terminal Joyoboyo belum memenuhi standar minimal dari konsep node-place model yang seharusnya masuk ke kategori balanced. . Hal ini menandakan bahwa pada kawasan Terminal Joyoboyo, jaringan transportasi umum yang ada di dalamnya masih kurang, sedangkan aktivitas maupun kegiatan yang berlangsung di kawasan tersebut sudah melebihi standar. Berdasarkan hal tersebut dapat diketahui bahwa kawasan Terminal Joyoboyo belum menerapkan konsep node-place model, sehingga karakteristik yang terdapat di dalamnya belum memenuhi kriteria minimal node-place model.

\section{DAFTAR PUSTAKA}

[1] O. Z. Tamin, Perencanaan dan Pemodelan Transportasi, 2nd ed. Bandung: Institut Teknologi Bandung, 2000.

[2] BAPPEDA Kota Surabaya, "Rencana Detail Tata Ruang UP. Kertajaya Tahun 2008-2018." Surabaya, 2008.

[3] H. Dittmar and G. Ohland, The new transit town: best practices in transit-oriented development. Island Press, 2004.

[4] R. Cervero, "Public Transport and Sustainable Urbanism: Global Lessons," 2006.

[5] R. Dunphy, Developing around transit: strategies and solutions that work / Robert T. Dunphy ... [et al.]. - Version details Trove. Washington, D.C. , 2004.

[6] M. O. Maureen and et al, "City of San Diego Guidance System: Transit Oriented Development Guidelines," 1992.

[7] Eltis The urban mobility observatory, "Transit-oriented development in Curitiba. Brazil | Eltis," 2014. [Online]. Available: http://www.eltis.org/discover/case-studies/transitoriented-development-curitiba-brazil. [Accessed: 20-Mar-2019].

[8] L. Bertolini, "Spatial Development Patterns and Public Transport: The Application of an Analytical Model in the Netherlands," Plan. Pract. Res., vol. 14, no. 2, pp. 199-210, May 1999.

[9] G. Giuliano, "Land Use Impacts of Transportation Investments: Highways and Transit," 2004. [Online]. Available: https://www.researchgate.net/publication/235360306_Land_Use _Impacts_of_Transportation_Investments_Highways_and_Trans it. [Accessed: 20-Mar-2019].

[10] D. E. Reusser, P. Loukopoulos, M. Stauffacher, and R. W. Scholz, "Classifying railway stations for sustainable transitions balancing node and place functions," J. Transp. Geogr., vol. 16, no. 3, pp. 191-202, May 2008.

[11] K. H. Dewi Martha Erli, "Penerapan TOD (Transit Oriented Development) sebagai Upaya Mewujudkan Transportasi yang Berkelanjutan di Kota Surabaya.," Surabaya, 2012.

[12] J. Luciano Renne, A. Assistant Professor of Urban, B. Tippett, and S. Kolapalli, "Measuring The Performance Of TransitOriented Developments In Western Australia Planning and Transport Research Centre Sponsored by the Western Australian Department for Planning and Infrastructure and the Public Transport Authority of Western Australia," 2007.

[13] I. Morojele, "Nodal intensification strategy: evaluation of an analytical model in metropolitan Cape Town," 2005. [Online]. Available:

https://www.researchgate.net/publication/44140014_Nodal_inten sification_strategy_evaluation_of_an_analytical_model_in_metr opolitan_Cape_Town. [Accessed: 20-Mar-2019]. 